\title{
ADMINITRASI PENDIDIKAN DAN TENAGA KEPENDIDIKAN
}

\author{
Nola nopita \\ Universitas Negeri Padang \\ Indonesia \\ E-mail : \\ nollanopita@gmail.com
}

\begin{abstract}
Abstrak
Administration of educators and education personnel is the overall process of the activities of educators to achieve educational goals effectively and efficiently.

In this article the author uses the literature study method, by collecting material sourced from review,journals and others related to the administrative processof educators and education personnel. The purpose of this article is to fulfill structured assignments in the Administration and Supervision of Education courses. And it is knowledge especially for compilers and generally for readers, regarding the Administration of Educators and Education Personnel
\end{abstract}

1. Konsep Dasar Administrasi Pendidik dan Tenaga Kependidikan (PTK)

a. Pengertian Administrasi Pendidik dan Tenaga Kependidikan (PTK)

Administrasi dalam pengertian secara harfiah, kata "adminitstrasi" berasal dari bahasa latin yang terdiri dari kata ad dan ministrare. Kata ad mempunyai arti sama dengan kata to dalam bahasa inggris yang berarti "ke" atau "kepada". Dan kata ministrare sama dengan kata to serve atau to conduct yang berarti melayani, membantu dan mengarahkan. Dalam bahasa inggris to administer berarti pula " mengatur, memelihara dan mengarahkan".
Jadi kata administrasi secara harfiah dapat diartikan sebagai kegiatan atau usaha untuk membantu, melayani, mengarahkan atau mengatur semua kegiatan didala mencapai suatu tujuan. ( Purwanto, 2007).

Fungsi adminstrasi, jika dihubungkan dengan adminnistrasi pendidik maka bisa diartikan bahwa hal ini merupakan upaya peningkatan efektifitas guru, dosen, dan lain lain utnuk mencapai tujuan pendidikan itu sendiri.

Pendidik

Secara umum pendidik di indonesia lebih dikenal dengan pengajar, adalah tenaga kependidikan yang berpartisipasi dalam menyelenggarakan pendidikan dengan tugas khusus sebagai profesi pendidik. Pendidik mempunyia sebutan lain sesuai kekhususannya, yaitu guru, dosen, konselor, pamong belajar, widyaiswara, tutor, instruktur, fasilitator. Sedangkan dalam UU No. 20 tahun 2003 BAB XI pendidik dan tenaga kependidikan pasal 39 mengatakan bahwa pendidik merupakan tenaga 
profesional yang bertugas merencanakan dan melaksanakan proses pembelajaran, menilai hasil pembelajaran, melakukan pembimbingan dan pelatihan, serta melakukan penelitian dan pengabdian kepada masyarakat terutama bagi pendidik di perguruan tinggi. Pendidik merupakan tenaga profesional, merancang pembelajaran, melaksanakan pembelajaran, menilai hasil pembelajaran, membimbing melatih meneliti mengabdi pada masyarakat.

Tenaga kependidikan

UU no 20 tahun 2003 BAB XI pendidik dan tenaga kependidikan pasal 39 yaitu, tenaga kependidikan bertugas melaksankan adminsitrasi, pengelolaan, pengembangan, pengawasan, dan pelayanan teknis untuk, menunjang proses pendidikan pada satuan pendidikan.

Tenaga kependidikan meliputi kepala sekolah/madrasah, pengawas satuan pendidikan, tenaga administrasi, tenaga kepustakaan, tenaga laboratorium, teknisi, pengelola kelompok belajar, pemong belajar dan tanag kebersihan.

Tenaga kependidikan lainnya, orang yang berpartisipasi dalam penyelenggaraan pendidikan disatuan pendidikan, walaupun secara tidak langsung terlibat dalam proses pendidikan, diantaranya:

1. Wakil wakil/kepala urusan umumnya pendidik yang mempunyai tugas tambahan dalam bidang yang khusus, untuk membantu kepala satuan pendidikan dalam penyelenggaraan pendidikan pada institusi tersebut. Contoh kepala urusan kurikulum

2. Tata usaha, adalah tenagak kependidkan yang bertugas dalam bidang adminisrasi intsitusi tersebut. Bidang adminsitrasi yang dikelolanya adalah administrasi surat menyurat dan pengarsipan, administrasi kepegawaian, administrasi peserta didik, administrai keuangan, administrasi inventaris dan lain lain.

3. Laboran, adalah petugas khusus yang bertanggung jawab terhadap alat alat dan bahan di laboratorium.

\section{Pustakawan}

5. Pelatihan ekstrakulikuler

6. Petugas keamanan (penjaga sekolah), petugas kebersiha dan lainnya.

Berdasarkan uraian tersebut maka dapat disimpulkan bahwa administrasi pendidik dan tenaga kependidikan adalah proses keseluruhan kegiatan pendidik yang meliputi perencanaan, pengorganisasian, pengarahan, 
pelaporan, pengkoordinasian, pengawasan dan pembiayaan, dengan menggunakan atau memanfaatkan fasilitas yang tersedia, baik personal, materiil, maupun spiritual untuk mencapai tujuan pendidikan secara efektif dan efesien.

\section{Proses administrasi PTK}

a. Pengadaan Tenaga kependidikan Pengadaan tenaga personil adalah proses kegiatan untuk mengisi formasi yang kosong. Perlu diketahui bahwa lowonganya suatu formasi, disamping disebabkan karena pengembangan lembaga dengan menambah jabatan-jabatan baru juga disebabkan oleh adanya personil-personil lembaga yang berhenti (Afriansyah. 2019) Pengadaan tenaga kependidikan diselengarakan dengan langkah-langkah sebagai berikut:

b. Pengumuman adanya formasi baru Pengumuman ini dilakukan untuk memberitahukan kepada seluruh masyarakat yang memenuhi kualifikasi melalui media cetak maupun media elektronik. Dalam pengumuman pengadaan tenaga kependidikan,hal yang harus tercantum adalah sebagai berikut:

1) Jenis atau macam pegawai yang dibutuhkan
2) Persyaratan yang dituntut dari para pelamar

3) Batas waktu dimulai dan diakhiri pendaftaran

4) Alamat dan tempat pengajuan pelamaran

5) Lain-lain yang dipandang perlu

b. Pendaftaran Pendaftaran dilakukan setelah pengumuman tersebar dan pendaftar mengajukan pemohonan dengan memenuhi syarat yang telah ditentukan beserta lampiran lainnya yang dibutuhkan.

c. Seleksi atau penyaringan Dalam pengadaan tenaga kependidikan, penyaringan dilaksanakan melalui dua tahap yaitu: 1) Penyaringan administrative Penyaringan administrative dilaksanakan berupa pemeriksaan terhadap kelengkapan beserta lampirannya. Apabila terdapat kekurangan lengkapan dalam hal administrative maka pesrta tersebut akan gagal. 2) Ujian atau test Setelah peserta yang lulus dala tes penyaringan administrative maka akan mengikuti ujian pegawai dengan materi pengetahuan umum, pengetahuan tehnis, dan lainnya yang dipandang perlu. Melakukan seleksi "personal references" atau "employment references"yang dapat dilakukan melalui dokumen-dokumen atau berkas-berkas 
lamaran yang masuk dan dapat pula dilakukan melalui kontak-kontak komunikasi lainnya. Penyelenggaraan "testing" secara tertulis misalnya penggunaan tes-tes psikologis (Psychological test), tes-tes pengetahuan (knowledge test) dan bentuk tes yang mengukur beberapa bagian pekerjaan yang akan diembankannya (performance test). 3) Pemeriksaan medis atau kesehatan calon, baik dengan menunjukkan informasi kesehatannya, maupun pemeriksaan yang dilakukan secara langsung oleh tim yang sengaja dibentuk (contoh: Tim Penguji Kesehatan untuk Calon Pegawai Negeri Sipil). d. Pengumuman Pengumuman ini berisi peserta yang lolos dalam seleksi sesuai ketentuan dan penempatan kerja.

d. Penempatan Penempatan merupakan tindakan pengaturan atas seseorang untuk menempati suatu posisi atau jabatan. Meskipun tindakan penempatan ini mengandung unsur uji coba yang menyebabkan adanya tindakan penempatan kembali namun pada dasarnya penempatan tenaga kependidikan merupakan tindakan yang menentukan keluaran dan komposisi ketenagaan dilihat dari kepentingan keseimbangan struktur organisasi pendidikan nasional. tindakan penempatan merupakan tindakan terpadu antara apa yang dapat tenaga baru perlihatkan (kerjakan) dengan tuntutan-tuntutan pekerjaan, kewajiban-kewajiban dan hal-hal yang ditawarkan dari jabatan tersebut. Karena itu suatu prinsip yang mengatakan "the right man on the right place" (orang yang tepat pada tempat yang tepat) haruslah dipenuhi. Dalam konteks penempatan ini, adanya mutasi (perpindahan pegawai) dari satu daerah ke daerah lain atau dari satu bidang kerja ke bidang kerja yang lain dapat dilakukan dengan memperhatikan kebutuhan. Kebutuhan tersebut dapat berkenaan dengan kebutuhan kuantitas maupun kualitas. Mutasi atau perpindahan di kalangan tenaga kependidikan dapat menjadi alternatif penting untuk pengembangan organisasi. Menurut Penempatan adalah proses penanganan pegawai baru yang sudah melaksanakan pendaftaran ulang untuk diberi tahu pada bagian seksi mana mereka ditempatkan. Penetapan atas calon-calon yang diterima dapat diputuskan oleh atasan langsung atau oleh bagian personalia/

kepegawaian. Keputusan ini merupakan akhir dari kegiatan penyelenggaraan seleksi. Artinya tenaga-tenaga kependidikan yang baru diterima.

e.orientasi 
Orientasi merupakan upaya memperkenalkan seorang tenaga kependidikan yang baru terhadap situasi dan kondisi pekerjaan atau jabatannya. Ada juga yang berpendapat orientasi adalah suatu proses pemberian pemahaman kepada peserta, tentang segala sesuatu yang berkaitan dengan latihan yang sedang diadakan. Tujuan agar seorang itu secepatnya dapat menyesuaikan diri terhadap orang-orang (tenaga kependidikan lainnya) atau para peserta didik, falsafah, maksud-maksud dan tujuan-tujuan yang mendasari pelaksanaan pekerjaan, kebiasaankebiasaan, usaha-usaha pembaharuan yang berlangsung, dan kesempatan-kesempatan untuk tumbuh dan berkembang dalam profesi atau karir di masa yang akan datang. Orientasi bertujuan untuk mempercepat masa adaptasi sehingga tenaga kependidikan baru dapat bekerja lebih depat dan lebih baik. Namun tidak semua orientasi menjamin hasil yang baik. Pemberian informasi yang tidak tepat dapat menimbulkan situasi yang buruk bagi tenaga kependidikan baru maupun organisasi atau perusahaan. Program orientasi sering juga disebut dengan induksi, yakni memperkenalkan para pegawai dengan peranan atau kedudukan mereka, dengan organisasi dan dengan pegawai lain (Nawawi, 1994).

\section{Kesejahteraan PTK}

a. Gaji Di dalam UU Nomor 14 Tahun 2005 tentang Guru dan Dosen dinyatakan bahwa yang dimaksud dengan gaji adalah hak yang diterima oleh guru atau dosen atas pekerjaannnya dari penyelenggaraan pendidikan atau satuan pendidikan dalam bentuk financial secara berkala sesuai dengan peraturan perundang-undangan. Ini berarti bahwa seorang guru (dalam hal ini guru PNS) akan diberi gaji berupa uang yang dibayarkan secara berkala. Berkala yang diamsud di sini adalah setiap bulan. Besarnya gaji yang diterima tersebut sesuai pangkat/golongan dan masa kerja. Di dalam Peraturan Pemerintah Republik Indonesia Nomor 25 Tahun 2011 tentang Perubahan Kedua Belas Peraturan Pemerintah Nomor 7 Tahun 1977 tentang Peraturan Gaji Pegawai Negeri Sipil, pada Bab II pasal 4 dinyatakan bahwa PNS (termasuk guru PNS) diberi gaji pokok berdasarkan golongan dan ruang yang ditetapkan untuk pangkat tersebut. Sedangkan pada pasal 5 dikatakan pula bahwa seorang yang diangkat menjadi calon Pegawai negeri Sipil diberi gaji poko $80 \%$ dari gaji pokok seperti yang dinyatakan pada pasal 4. Selain diberi gaji pokok, seorang 
PNS (termasuk guru) akan mendapat kenaikan gaji berkala apabila telah memenuhi persyaratan seperti: telah mencapai masa kerja golongan dan penilaian pelaksanaan pekerjaan sekurangkurangnya cukup. Di samping kenaikan gaji berkala, seorang PNS (guru PNS) juga diberi tunjangan keluarga dan tunjangan jabatan.

Di dalam Bab IV pasal 14 ayat 1 (a) UU Nomor 14 Tahun 2005 tentang Guru dan Dosen dinyatakan pula bahwa dalam melaksanakan tugas keprofesionalannya guru berhak memperoleh penghasilan di atas kebutuhan hidup minimum dan jaminan kesejahteraan social. Selanjutnya pada pasal 15 dinyatkan pula bahwa yang dimaksud penghasilan di atas kebutuihan hidup minimum tersebut meliputi; gaji pokok, tunjangan yang melekat poada gaji, serta penghasilan lain berupa tunjangan profesi, tunjangan fungsional, tunjangan khusus, dan maslahat tambahan yang terkait dengan tugas sebagai guru yang ditetapkan berdasarkanb prinsip penghargaan atas dasar prestasi.

b. Tunjangan Tunjangan profesi diberikan kepada guru yang telah memiliki sertifikat pendidik yang diangkat oleh penyelenggarakan pendidikan dan satuan pendidikan yang diselenggarakan oleh masyarakat. Besarnya tunjangan profesi adalah sebesar gaji pokok guru tersebut. Tunjangan profesi tersebut dialokasikan dalam anggaran pendapatan dan belanja negara $(\mathrm{APBN})$ dan/atau anggaran pendapat belanja daerah (APBD). Hal ini dinyatakan dalam pasal 16 ayat 2 dan 3 UU Nomor 14 tahun 2005 tentang Guru dan Dosen saja, tapi boleh juga dalam alokasi APBD. Namun sampai tahun 2011 ini pembayaran tunjangan profesi guru belum dibebankan pada APBD kabupaten/kota. Di samping gaji pokok, tunjangan keluarga (istri/suami dan anak) tunjangan fungsional, tunjangan profesi, di beberapa daerah guru juga mendapat insentif atau yang sejenis dengan itu dari dana APBD kabupaten/kota di tempat guru tersebut bertugas. Besarnya tentulah beragam sesuai dengan kemampuan keuangan daerah. Pemberian gaji dan berbagai tunjangan terhadap guru tersebut bertujuan untuk meningkatkan kesejahteran guru. Tentu dengan tingkat kesejahteran yang baik seorang guru dapat menjalankan tugasnya dengan baik pula. Guru tidak lagi harus bekerja sampingan yang dapat membuat dia mengabaikan tugasnya sebagai pendidikan di sekolah. Tentu dengan harapan, jika guru tersebut dapat mencurahkan perhatiannnya di sekolah, 
mutu pendidikan akan bisa ditingkatkan. Mekipun sesungguhnya tidak menjamin dengan peningkatan kesejahteraan guru mutu pendidikan akan meningkat. Namun kita mungkin sepakat bahwa bila kesejahteraan guru diturunkan tidak akan mampu menaikkan mutu pendidikan. Bahkan bisa dipastikan mutu pendidikan akan merosot tajam. Hal tersebut barangkali disebabkan semangat dan gairah guru akan menurun bila kesejahteraannya diturunkan.

c. Penghargaan Pemerintah memberikan sebuah penghargaan di institusi pendidikan terhadap guru, dosen, kepala sekolah, dan seluruh tenaga pendidik yang berprestasi. Penghargaan PTK berprestasi ini sebagai penggerak perubahan dalam kemajuan mutu pendidikan. Direktur Jenderal Pendidikan Menengah Kementerian Pendidikan dan Kebudayaan (Dirjen Dikmen Kemdikbud) Achmad Jazidie mengatakan, tujuan diberikannya penghargaan adalah untuk meningkatkan kualitas sumber daya manusia (SDM). Tujuan lainnya, adalah untuk dapat meningkatkan mutu pendidikan ke arah yang lebih baik.

Penilaian PTK berprestasi sesuai dengan standar yang ditentukan mulai dari menilai aspek kompetensi pedagogik, kompetensi kepribadian, kompetensi sosial, kompetensi profesional, dan menguasai teknik-teknik pembelajaran. "PTK berprestasi sebagai pelopor pengimplementasian Kurikulum 2013. Pemilihan PTK berprestasi dilakukan berjenjang mulai dari tingkat satuan pendidikan, kabupaten, provinsi, dan nasional. Kemudian diseleksi lagi dengan beberapa kriteria sampai terpilih peringkat 1 , 2, dan 3. "Kegiatan pemilihan PTK berprestasi merupakan salah satu bentuk perhatian pemerintah terhadap para guru, kepala sekolah, serta pengawas pendidikan (Asnawir, 2005)

4. Cuti PTK Cuti adalah keadaan tidak masuk kerja yang diijinkan dalam jangka waktu tertentu. Jenis-jenis cuti: 1. Cuti Tahunan a. Hak Cuti Tahunan i. Merupakan hak PNS, termasuk CPNS yang telah bekerja secara terus menerus selama 1 (satu) tahun. ii. CPNS hanya berhak atas cuti tahunan, kecuali ditentukan lain oleh pejabat yang berwenang memberikan cuti berdasarkan pertimbangan kemanusiaan. iii. Selama menjalankan cuti tahunan, PNS/CPNS yang bersangkutan memperoleh TKPKN. b. Penggunaan Cuti Tahunan i. Penggunaan cuti tahunan dapat digabungkan dengan cuti bersama, dengan jumlah paling sedikit menjadi 3 (tiga) hari kerja ii. Cuti bersama yang tidak digunakan karena kepentingan dinas dan berdasarkan surat 
tugas, tetap menjadi hak cuti tahunan PNS 2. Cuti Besar a. Hak cuti besar i. Merupakan hak PNS yang telah bekerja paling kurang 6 (enam) tahun secara terus menerus. ii. PNS yang akan/telah menjalani cuti besar tidak berhak lagi atas cuti tahunan dalam tahun yang bersangkutan. iii. Selama menjalankan cuti besar, PNS yang bersangkutan tidak berhak atas tunjangan jabatan dan tidak memperoleh TKPKN. b. Penggunaan Cuti Besar i. PNS perlu merencanakan penggunaan cuti besar sejak awal tahun.Cuti besar dapat digunakan oleh PNS untuk Memenuhi kewajiban agama, Persalinan anaknya yang keempat apabila PNS yang bersangkutan mempunyai hak cuti besar menjelang

persalinan,Keperluan lainnya sesuai pertimbangan pejabat yang berwenang memberikan cuti. ii. PNS yang telah melaksanakan cuti tahunan dan akan mengambil cuti besar pada tahun yang bersangkutan harus mengembalikan TKPKN yang diterimanya selama melaksanakan cuti tahunan. 3. Cuti Sakit a. Hak Cuti Sakit merupakan hak PNS dan/atau PNS/CPNS wanita yang mengalami gugur kandungan. b. Penggunaan Cuti Sakit i. PNS yang menderita sakit lebih dari 2 (dua) hari harus melampirkan surat keterangan dokter dari rumah sakit pemerintah/puskesmas. ii. PNS yang telah menggunakan cuti sakit untuk jangka waktu paling lama 1 (satu) tahun 6 (enam) bulan dan telah aktif bekerja kembali 4. Cuti Bersalin a. Hak Cuti Bersalin i. Merupakan hak PNS/CPNS wanita untuk persalinan anaknya yang pertama, kedua, dan ketiga ii. Cuti bersalin yang digunakan oleh CPNS wanita untuk persalinan anaknya yang pertama akan mengurangi hak cuti persalinan setelah yang bersangkutan menjadi PNS 5. Cuti Karena Alasan Penting a. Hak Cuti Karena Alasan Penting i. Merupakan hak PNS ii. Selama menjalankan cuti karena alasan penting, PNS yang bersangkutan tidak memperoleh TKPKN b. Hak Cuti bagi PNS yang Sedang Tugas Belajar PNS yang sedang tugas belajar di dalam negeri atau di luar negeri yang akan menggunakan cuti bersalin dan cuti besar untuk persalinan anaknya yang keempat (apabila yang bersangkutan mempunyai hak cuti besar menjelang persalinan) harus mengajukan permohonan cuti kepada pejabat yang berwenang memberikan cuti melalui Pimpinan Perguruan Tinggi atau Kepala Perwakilan Republik Indonesia di negara yang bersangkutan (Sugito, 2011 